\title{
USAGE OF IDIOMS WITH THE CONCEPT "BLACK" IN THE ENGLISH AND KARAKALPAK LANGUAGES
}

\author{
Abdullaeva Dilbar \\ Assistant Teacher, Foreign Languages Department, Nukus State Pedagogical Institute \\ Nukus, Karakalpakstan, Uzbekistan
}

Article DOI: https://doi.org/10.36713/epra8441

DOI No: 10.36713/epra8441

\begin{abstract}
The article deals with the importance of using idioms, peculiarities, semantic meanings, and formation of idiomatic expressions. In this article, idioms with the concept "black" in the English and Karakalpak languages have been analyzed and examples are provided. Comparative and descriptive methods analyses are used in this article. The article gives information about the problem of understanding and using idioms with foreign speakers lies in the definition of an idiom. Also, in the article, black color in the Karakalpak culture is explained and the reason of why this colour mostly associated with the negative concepts has been defined.
\end{abstract}

KEY WORDS: idioms, black, English and Karakalpak language, idiomatic expressions.

\section{INTRODUCTION}

The significance of theory on conceptual metaphor is extremely important while talking about idioms and their relationship with the culture. Dobrovolski and Piirainen [1] state that, each culture comprehends the same phenomenon in a different manner. They carried out an analysis of number perception in the English, Lithuanian and German languages. The same phenomenon was brought out by the means of a different number, even though the cultures are not so extremely diverse. Scholars suggest the idea that all the idioms were based on one conceptual metaphor "Happy is up", however, number were chosen differently as different numbers have a historical significance in different cultures. For instance, number 7 is characteristic to Western cultures, whereas number nine is common to NorthEuropeans. Idioms as culture specific elements cause numerous problems not only in intercultural communication but also in translation. Language acquisition is usually related to the acquisition of foreign culture, as in many cases it helps to perceive the linguistic system in a better way. Moreover, each language possesses its individual peculiarities, all language have common elements. In this case, idioms as culture specific elements could be perceived in an easier way if the acquisition starts from common and comes to specific. Some linguists rely on the classification provided by Vinogradov. Indeed, his input into the investigation of phraseology is significant and valid until nowadays. According to Gozdarev [2] the basis for Vinogradov's classification was the relationship between separate components of the phraseological unit with the overall meaning of an idiom, whereas such a relationship might be different. The latter observations led to the distinguishing of three major types of idioms in the following: 1) Analytical - the meaning of each component could be distinguished; 2) Synthetic - idioms possessing one synthetic meaning; a) Motivated by the direct meaning of the elements (phraseological unities); b) Not motivated by the direct meaning of the elements (phraseological fusions).

\section{LITERATURE REVIEW}

It might be a challenging task to define the notion of idioms. However, it is rather difficult to decide on the nature of idioms as well. As Seidl and McMordi state that a phrase has to be used for a long period of time to be called an idiom therefore possible ways for the idiom to enter the language should be discussed [7]. According to Seidl and McMordi it is important to stress the fact that idioms could be defined according to other criteria such as: 1) Idioms appear in formal as well as in the colloquial styles; 2) A whole unit possesses one meaning rather than words taken separately; 3) Parts 
of idioms are not interchangeable; 4) Some idioms may be characterized as illogical and ungrammatical; 5) Long usage defines the phrase as an idiom [7]. When we refer to Jack, in many cases, it is possible to recognize the roots of idioms, in some cases, idioms originate from the historical events, in others idioms originate from unbelievable events but in most of the cases there is an explanation how one or another idiom ended up in the language use [3]. Also, Garcia stresses the fact that the major sources for the idiom formation are the following: literature, mythology, religion, folklore, and culture diversity [8]. The formation of idioms just like the formation of new words show that the language still functions. Referring to Gozdarev newly coined idioms have a special name - phraseological neologisms [2]. He notes that in most of the cases new idioms are coined by one person and are considered as phraseological units only when people start actively using it. The drawback of this phenomenon is that the authors of the idioms usually remain in the dark. Furthermore, Gozdarev notes that semantic classification depends on the level of motivation between the elements. Therefore, those three types of semantic classification are: phraseological collocations, phraseological unities and phraseological fusions [2]. However, if we consider the works of $\mathrm{M}$. Qudaybergenov and Sh. Xojanov, this may not be true if we refer to the famous authors who also take part in the creation of phraseology, just like in the Karakalpak language: Berdakh, I.Uysupov, T.Qayipbergenov and J.Aymurzaev are accounted for a great source for phraseological neologisms [4]. Also, Qudaybergenov states that using idioms with contrastive meaning is one of the pecularities of Karakalpak culture. He stresses that idioms' meanings could be compared in defining criteria of the components of antonymic idioms as idioms are distinguished with their specific components and sematic pecularities described in the respect of expression, as stable grammatical units which are learnt once and for all and used without reinvention. Semantic properties idioms can be paraphrased in one word. Taking into account the usage of idioms, they could be used in a particular lexical environment without which they cannot function as idioms.

\section{RESULTS AND DISCUSSION}

In the Karakalpak culture black colour is closely related to either hard life or hard work. The concept of difficult wellbeing is expressed through number of idioms and examples indicate this point of view. The example could also be ascribed to the group of bad living conditions as it expresses the idea of poor nutrition. The concept of hard work is expressed through idioms. Along with the hard life, black colour is used to express worries and sadness about danger. Black colour idioms could be used for a character building describing negative aspects of a person. The description may start with the representation of a social class, black colour is used to describe people who belong to the lowest social strata, and physical appearance which involves such description as poorly-looking could be expressed with the help of the idiom. Personal characteristics such as being an extremely ill-natured person who is cruel to people and curse and scolds, being unfair to someone and being poor, gloomy and unsociable could be expressed with the help of the Karakalpak black colour idioms.

In the following, we have analyzed some idioms using the concept "black" in the English and Karakalpak languages with some examples: ko'gertiw;

1. Black somebody's eyes - birewdin' ko'zin

For example: There was a man and he was bothering me and he wouldn't stop and she glanced at Angus, and the laughter bubbled in her again, he made him go outside and blacked his eyes. (Catherine Cookson. The Round Tower).

2. Be in black - qara jamiliw, qayg'iriw;

For instance: Why don't you have a party at Christmas, lass, and come out of yourself? As long as you still wear black you are still in the grave with him. Let the dead bury the dead, as the saying goes. (Catherine Cookson. Tilly Trotter widowed Part One).

3. A black ingratitude - duzin jep tuzlig'ina tu'piriw, jaqsiliq jaqpaw, da'm tatqan qudiqqa tu'kiriw, jaqsiliqti bahalamaw;

For instance: She answered with black ingratitude to my hospitality.

4. Black money - nizamsiz tu'rde yamasa urliq penen, birewdi aldaw arqali tabilg'an aqsha.

5. Black sheep occurs in all families It is a small flock that has not a black sheep;

For instance: There is a black sheep in every flock - Qara qoy barliq waqitta qorada boladi; Elde bir tentek ju'rmey me qoylardin' shaytan menen baylanisi bar.

6. Black and blue all over - ko'k qara qoyday, birewdin' urg'aninan yamasa bir na'rsege uring'annan denesi ko'geriw (be, beat somebody).

For example: My first husband, Captain Johnson used to trash me regularly. He was a man. He was handsome, six foot three and when he was drunk there was no holding him. It would be black and blue all over for days at a time. (Somerset Maugham.The moon and Sixpence).

7. A black frost - qara suwiq, qarsiz, izg'arli suwiq.

For example: And then there was the morning of the first really hard frost, a black frost. There was a patch of ice outside the door some yards long and impulsively I slid along it, much to my 
parents' amusement. (Catherine Cookson. The Hause of Men).

8. A black hen lays a white egg - qara tawiq aq ma'yek tuwadi, qara siyirdin' su'ti aq boladi, shirayli emes bolg'ani menen ishki qa'siyeti jaqsi.

9. In black and white - aqqa qara basqanday aniq, alaqang'a salg'anday, aydan aniq (get, have, put something, state).

For example: If he wanted money, there was no money and accounts in black and white proved it. (Edward Behr. the Last Emperor).

10. Go into black - qara jamiliw, aza tutiw.

For example: You know Leonard did not with me go into black or have the house mouring.

11. Prove that black is white, make out black was white - qarani aq dew, o'tirik so'ylew; For example: These men with their words and their cleverness, they could make out black was white.

Therefore, the actions of treating politely could be presented with the contribution of black color as well. In addition, black colour could also be related to the positive phenomenon as it warns against being in touch with bad people as they can spoil good people. Black colour is usually associated with the colour of a yurt. Thus, Karakalpak people used to take their house when moving from one place to another has a figurative meaning "A big united family" darkness, therefore such idioms as and help to figuratively describe the class of people. One more meaning of black colour is connected with beauty: black-eyed, black-haired. Writers to portray girl's quality 3 or more colours: black eye, black currant eye, eye like sheep, eyes like coal, black hair like silk. For example, if the girl's eyes were big and black, such eyes were compared with currant.

\section{CONCLUSION}

Thus, an idiom is a phrase or an expression that has a figurative or sometimes literal meaning. Categorized as formulaic language, an idiom's figurative meaning is different from the literal meaning. There are thousands of idioms occurring frequently in all languages. As idioms are used in our everyday life and people use them unconsciously they may cause a lot of misunderstandings between the speakers of different languages. As Liu notes idioms are part of culture-specific elements [6], relying on Yoko idioms constantly cause communication breakdowns [9]. The problem of understanding and using idioms with non-native speakers lies in the definition of an idiom. We have seen that black color in the Karakalpak culture is mostly associated with the negative concepts, it reflects the temper of Karakalpak culture, culture where people work hard and still live hard, with the help of black color idioms it is possible to form a personality who belongs to the lowest social class, is bad looking, possesses a number of negative personal traits. Moreover, black colour is treated as natural colour: colour of the earth, sign of prosperity. This philosophical notion meaning constancy, statics: "naked earth", "common people", "matchlock gun", "black horse", "maid who does spade work". Contrary concepts of darkness and clearness are expressed via black colour idioms. However, those are not the only contradictions of the black colour idioms, as they express the concept of everything, nothing and anything.

\section{REFERENCES}

1. Dobrovolskiy D., Piirainen E. 2006. Cultural Knowledge and idioms. International Journal of English Studies. 6/1. pp. 27-41.

2. Gozdarev, Yu.A. Sovremenny Russkiy yazik: Leksikologiya i Frazeologiya.

3. Moskva-Rostov na Donu: Mart. 2009. pp. 212340.

4. Jack A. 2004. Red Herrings and White Elephants. London: HarperCollins Publishers. p. 3.

5. Berdimuratov E. Ha'zirgi qaraqalpaq leksikologiyasi. Nukus, 1994. pp. 147-149.

6. Bespontovaya N.S. Yazikovoy determinism I Russkaya Frazelogiya. Moskva. 2010.

7. Liu D. Translation and Culture: Translating Idioms between English and Chinese from Cultural Perspective. Theory and Practice in Language Studies. 11/2: 2357-2362. 2012.

8. Seidl J., McMordie W. 1983. English Idioms and How to Use Them. Moscow: Vysšaja Škola. pp. 7.

9. Garcia M.J. Idiomatic Expressions Influenced by the Greek and Roman cultures. Memorias del vi foro de estudios en lenguas internacional. 2010. pp. 410-416.

10. Yoko I. 1993. The study of idioms and its application to ESL and intercultural communication, accessed November, 15. 2014, available from:

http://scholarworks.sjsu.edu/cgi/viewcontent.cgi?a rticle $=1628 \&$ context $=$ etd_these. 